\title{
PERBEDAAN ASUPAN ENERGI, PROTEIN DAN STATUS GIZI ANAK USIA PRA SEKOLAH DI SEKOLAH DENGAN MODEL SCHOOL FEEDING DAN NON SCHOOL FEEDING
}

\author{
Sunarti \\ Fakultas Kesehatan Masyarakat, Universitas Ahmad Dahlan Yogyakarta \\ inart2020@yahoo.com
}

\begin{abstract}
Background: Common problem in pre school children is macronutrien and micronutrien defisiensi. In Indonesia, prevalention of severely undernutrition is $8,3 \%$, and moderate undernutrition is $27.5 \%$. Prevalention of stunted are $46.6 \%$ for boys in Indonesia and $45.5 \%$ for girls in Indonesia. Increasing trend of full day school model for pre school children with school feeding gives positif contribution by increasing children nutritional status. The objective of this research was to compare the difference of energy intake, protein intake and nutritional status of pre school children with school feeding and non school feeding model.
\end{abstract}

Methods: The reseach design was cross sectional study that assesed variables in one point in time.

Results: This results showed that there were differences of energy intake, protein intake and nutritional status (z-score) of pre school children with school feeding and non school feeding model with $p$ value 0.000 .

Conclution: There were differences of energy intake, protein intake and nutritional status (zscore) of pre school children with school feeding and non school feeding model.

Key word : nutritional status, school feeding, pre school

\begin{abstract}
ABSTRAK
Latar belakang: Permasalahan umum yang dialami anak usia pra sekolah di Indonesia adalah defisiensi gizi, baik makronutrient maupun mikronutrien. Prevalensi gizi buruk pada anak usia pra sekolah sebesar $8,3 \%$ dan gizi kurang sebesar $27,5 \%$. Prevalensi stunting sebesar $46,6 \%$ untuk laki-laki di Indonesia dan 45,5\% untuk perempuan di Indonesia. Maraknya model pendidikan usia dini dengan pendekatan full day school sesungguhnya memberikan kontribusi yang positif terhadap peningkatan status gizi anak usia pra sekolah. Tujuan dari penelitian ini adalah untuk membandingkan perbedaan asupan energi, protein, dan status gizi anak usia pra sekolah dengan model school feeding dan non school feeding.

Metode: Penelitian ini menggunakan desain cross sectional, dimana variabel diteliti dalam satu titik waktu.

Hasil: Hasil ini menunjukkan adanya perbedaan asupan energi, protein, dan status gizi (zscore) anak usia pra sekolah dengan model school feeding dan non school feeding yaitu dengan $p$ value sebesar 0,000 .

Kesimpulan: Ada perbedaan asupan energi, protein, dan status gizi (z-score) anak usia pra sekolah dengan model school feeding dan non school feeding.
\end{abstract}

Kata kunci: status gizi, school feeding, pra sekolah

\section{PENDAHULUAN}

Permasalahan umum yang dialami anak usia pra sekolah adalah defisiensi gizi baik makronutrient maupun mikronutrien. Di Indonesia, pada tahun 2003 prevalensi gizi buruk pada anak usia pra sekolah $8.3 \%$ dan gizi kurang $27.5 \%{ }^{1} \mathrm{Di}$ Indonesia, pada tahun 2001 prevalensi stunting laki-laki sebesar $46.6 \%$ dan 
perempuan $45.5 \%{ }^{1}$ Angka tersebut masih tergolong tinggi dan merupakan masalah yang cukup serius. Prevalensi stunting menggambarkan kekurangan gizi dalam tingkatan yang kronis. Kekurangan gizi yang terjadi pada masa balita akan berdampak pada masa berikutnya. Stuntet yang terjadi pada masa balita akan berakibat pada stauted pada usia berikutnya. Berdasarkan data pengukuran tinggi badan anak baru sekolah (6-9 tahun) didapatkan data stunted $36.1 \%$ pada tahun 1999. ${ }^{2}$ Masalah gizi kurang tidak hanya terkait dengan masalah kemiskinan akan tetapi terkait pula dengan aspek sosial dan budaya yang menunjang terjadinya pola asuh yang salah pada anak.

Dampak yang ditimbulkan dari masalah kurang gizi pada anak usia pra sekolah dapat mengancam kualitas sumber daya manusia. UNICEF 1998 dalam artikel Hadi (2005) mengatakan bahwa pada anak-anak yang stunted mempunyai IQ 11 point lebih rendah jika dibanding dengan anak - anak yang tidak stunted. Karena itu pemenuhan gizi pada anak sangat penting untuk mencegah terjadinya hambatan pertumbuhan pada fase berikutnya. ${ }^{3}$

Maraknya model pendidikan usia dini dengan pendekatan full day school sesungguhnya memberikan kontribusi yang positif terhadap peningkatan status gizi anak usia pra sekolah. Pada sekolah dengan model full day school umumnya menyelenggarakan pemberian makanan di sekolah (School feeding). Secara tidak langsung pemberian makanan di sekolah memberikan pengaruh terhadap keteraturan pola makan anak usia pra sekolah yang notabene mempunyai kebiasaan yang tidak teratur pada saat sarapan dan makan siang. ${ }^{4}$ Model school feeding merupakan solusi alternatif penyelesaian masalah gizi kurang pada anak sekolah dan anak pra sekolah. Dengan penyelenggaraan makan yang meliputi snack pagi, makan siang dan snack sore diharapkan akan menambah asupan gizi bagi anak usia pra sekolah.

Pelaksanaan program school feeding di Jamaika memberikan hasil bahwa pengurangan kelaparan disekolah merupakan salah satu mekanisme untuk memudahkan penerimaan pelajaran di sekolah. Pada program ini terbukti anak dengan gizi kurang lebih diuntungkan dengan keberadaan program school feeding dibandingkan dengan anak normal. ${ }^{5}$

Penelitian ini bertujuan mengetahui perbedaan asupan energi dan protein sehari, serta status gizi pada anak pra sekolah dengan school feeding dan non school feeding.

\section{METODE PENELITIAN}

Metode penelitian yang digunakan dalam penelitian ini adalah observasional analitik dengan pendekatan cross sectional dimana variabel sebab dan akibat diukur dalam satu titik waktu yang sama. ${ }^{6}$

Besar sampel yang digunakan dalam penelitian ini 76 responden yaitu 38 responden berasal dari siswa dengan model school feeding dan 38 responden dari siswa dengan model non school feeding. Teknik sampling yang digunakan dalam penelitian ini adalah simpel random sampling. ${ }^{7}$

\section{HASIL PENELITIAN DAN PEMBAHASAN}

\section{A. Hasil Penelitian}

\section{a. Gambaran Umum Wilayah Penelitian}

TK ABA Aisiah dan TK ABA Imam Syuhada merupakan taman kanak-kanak yang ada di wilayah PCA Blimbing. Perbedaan kedua TK tersebut terletak pada model sistem pendidikannya. Pada TK ABA Aisiah menggunakan sistem konvensional yaitu sistem pendidikan sesuai standar 
Departemen Pendidikan Nasional. Sedangkan pada TK Imam Syuhada menggunakan sistem Islam Terpadu yang pelaksanaan pembelajarannya dengan sistem full day school.

Berdasarkan karakteristik orang tua ada sedikit perbedaan antara orang tua yang menyekolahkan anak di full day school dengan TK konvensional. Kebanyakan yang di full day school adalah orang tua yang bekerja di luar rumah sehingga mereka merasa nyaman menyekolahkan anak di TK full day karena anak bisa terdidik dengan baik. Sementara orang tua yang di TK konvensional kebanyakan mereka adalah ibu rumah tangga dimana mereka punya waktu khusus untuk menunggu anaknya.

b. Hasil Penelitian

Tabel 1. Karakteristik Responden Berdasarkan jenis Kelamin

\begin{tabular}{lcc}
\hline \multicolumn{1}{c}{ Jenis Kelamin } & Frekuensi & prosentase \\
\hline Laki-laki & 40 & $52,6 \%$ \\
Perempuan & 36 & $47,4 \%$ \\
Total & 76 & $100,0 \%$ \\
\hline
\end{tabular}

Berdasarkan Tabel 1 dapat diketahui bahwa jumlah sampel anak laki laki lebih banyak dari pada anak perempuan $(52,6 \%)$.

Tabel 2. Karakteristik responden berdasarkan umur

\begin{tabular}{|c|c|c|}
\hline Umur & Frekuensi & Prosentase \\
\hline 7 tahun & 6 & $7,9 \%$ \\
\hline 6 tahun & 57 & $75,0 \%$ \\
\hline 5 tahun & 13 & $17,1 \%$ \\
\hline Total & 76 & $100,0 \%$ \\
\hline
\end{tabular}

Berdasarkan Tabel 2 tersebut dapat diketahui bahwa sebagian besar anak yang menjadi subjek penelitian berumur enam tahun yaitu 57 anak $(75 \%)$.

Tabel 3. Karakteristik responden berdasarkan pendidikan ibu

\begin{tabular}{lcc}
\hline \multicolumn{1}{c}{ Pendidikan } & Frekuensi & Prosentase \\
\hline Tamat SD & 9 & $11,8 \%$ \\
Tamat SLTP & 16 & $21,1 \%$ \\
Tamat SLTA & 28 & $36,8 \%$ \\
Tatat Diploma & 5 & $6,6 \%$ \\
Sarjana & 18 & $23,7 \%$ \\
Total & 76 & $100,0 \%$ \\
\hline
\end{tabular}

Berdasarkan Tabel 3 tersebut dapat diketahui sebagian besar pendidikan ibu dari anak yang menjadi subjek penelitian yaitu SLTA, sebanyak 28 orang $(36.8 \%)$.

Tabel 4. Karakteristik responden berdasarkan penghasilan orang tua

\begin{tabular}{lcc}
\multicolumn{1}{c}{ Penghasilan } & Frekuensi & Prosentase \\
\hline$\leq 1$ Juta & 22 & $28,9 \%$ \\
$>1$ juta sd 5 juta & 47 & $61,8 \%$ \\
$>5$ jt & 7 & $9,3 \%$ \\
Total & 76 & $100,0 \%$ \\
\hline
\end{tabular}

Berdasarkan data tersebut dapat dilihat bahwa tingkat penghasilan orang tua subjek penelitian sebagian besar sudah melebihi dari satu juta. 
Tabel 5. Perbedaan status gizi pada anak dengan model school feeding dan non school feeding

\begin{tabular}{lcccc}
\hline \multicolumn{1}{c}{ Model Sekolah } & $\mathrm{N}$ & Mean & Std. Deviation & $\mathrm{P}^{*}$ \\
\hline Non School feeding & 38 & -0.9749 & 0.841 & 0.000 \\
School feeding & 38 & -0.1397 & 1.165 & 0.000 \\
\hline$\left.{ }^{*}\right)$ Uji t & & & &
\end{tabular}

Berdasarkan data tersebut dapat diketahui bahwa ada berbedaan mean rata-rata nilai $z$ score pada anak yang sekolah di sekolah dengan model school feeding dan non school feeding.

Tabel 6. Perbedaan Asupan Energi dengan persen AKG pada anak dengan model school feeding dan non school feeding

\begin{tabular}{lcccc}
\hline \multicolumn{1}{c}{ Model sekolah } & $\mathrm{N}$ & Mean & Std. Deviation & $\mathrm{P}^{*}$ \\
\hline Non School feeding & 38 & 73.43 & 20.63 & 0.000 \\
School feeding & 38 & 89.70 & 20.92 & 0.000 \\
\hline${ }^{*}$ ) Uji t & & & &
\end{tabular}

Berdasarkan Tabel 6 tersebut dapat diketahui bahwa ada perbedaan asupan energi per hari pada anak yang sekolah dengan model school feeding dan non school feeding. Pada anak yang sekolah di sekolah dengan model school feeding mean rata-rata asupan energinya lebih tinggi dibanding dengan anak yang sekolah di sekolah dengan model non school feeding.

Tabel 7. Perbedaan Asupan Protein dengan persen AKG pada anak dengan model school feeding dan non school feeding

\begin{tabular}{lcccc}
\hline \multicolumn{1}{c}{ Model sekolah } & $\mathrm{N}$ & Mean & Std. Deviation & $\mathrm{P}^{*}$ \\
\hline School feeding & 38 & 146.74 & 56.49 & 0.000 \\
Non School feeding & 38 & 103.24 & 32.72 & 0.000 \\
\hline
\end{tabular}

*) Uji t

Berdasarkan Tabel 7 tersebut dapat dketahui ada perbedaan asupan protein pada anak yang sekolah di sekolah dengan model school feeding dengan anak yang sekolah disekolah dengan model non school feeding. Rata-rata asupan protein pada anak dengan model school feeding lebih tinggi dibandingkan anak yang sekolah dengan model non school feeding.

Tabel 8. Hubungan Asupan Energi dengan Status Gizi pada anak dengan model school feeding dan non school feeding

\begin{tabular}{cccc}
\hline Asupan Energi & $\mathrm{N}$ & $\mathrm{R}$ & $\mathrm{P}^{*}$ \\
Status Gizi & 76 & 0.292 & 0.01 \\
\hline$\left.{ }^{*}\right)$ Uji person korelasi & & &
\end{tabular}

Berdasarkan uji korelasi dengan person kolerasi didapatkan data bahwa ada hubungan antara asupan energi dengan status gizi dengan nilai $r$ 0,292 dan nilai $p$ value 0,01 . 


\section{B. Pembahasan}

\section{a. Perbedaan asupan energi pada anak dengan model school feeding dan non school feeding}

Asupan energi diperoleh dari pemecahan karbohidrat, protein dan lemak dari asupan makanan sehari-hari. ${ }^{8}$ Penentuan kebutuhan energi didasarkan pada basal metabolisme rate dan kegiatan fisik seseorang. Sedangkan basal metabolisme rate dipengaruhi oleh usia, jenis kelamin, auhu lingkungan, penyakit dan komposisi tubuh. ${ }^{8}$ WHO merekomendasikan bahwa asupan energi diperoleh karbohidrat $60-75 \%$, lemak $10-25 \%$ dan protein $10-15 \%{ }^{9}$

Hasil penelitian ini menunjukkan ada perbedaan rata-rata asupan energi sehari pada anak yang sekolah dengan model school feeding dan non school feeding. Pada anak yang sekolah dengan model school feeding asupan energi mencapai 103.6 persen AKG sementara anak yang sekolah di sekolah dengan model non school feeding mempunyai asupan energi 80.82 persen AKG.

Pada hasil tersebut walaupun berbeda secara signifikan akan tetapi asupan energi pada kedua kelompok tersebut tergolong cukup. Menurut Supariasa (2002) bahwa asupan energi 80-100 \% dari AKG sudah tergolong baik. ${ }^{10}$ Kecukupan energi merupakan hal yang sangat penting terutama pada masa-masa pertumbuhan. Anak golongan umur 1-6 tahun merupakan golongan usia rentan terhadap penyakit kurang gizi seperti kurang energi protein, anemia defisiensi besi, kurang vitamin A dan beberapa penyakit infeksi. ${ }^{11}$ Walaupun pada usia pra sekolah anak masuk pada fase pertumbuhan lambat (growth plateu), kecukupan energi tetap perlu dipertimbangkan untuk mengimbangi aktivitas fisik dan mekanisme balance ketika terjadi infeksi. ${ }^{12}$ Berdasarkan data asupan energi pada penelitian ini dapat diinterpretasikan bahwa anak usia pra sekolah di TK aisiah cabang blimbing tidak mengalami kekurangan asupan energi.

Pada penelitian ini ditemukan bahwa asupan energi siang hari pada kedua model sekolah tersebut tidak berbeda secara signifikan. Penelitian Sukendro (2012) pada lokasi yang sama menemukan bahwa tidak ada perbedaan asupan energi siang hari pada anak dengan model school feeding dan non school feeding dengan nilai $p$ value $0,131 .^{13}$ Pada siang hari anak yang sekolah dengan model school feeding mendapatkan asupan makanan tambahan dari jajan yang ada di sekitar sekolah mereka. Ini berarti pada anak yang sekolah dengan model non school feeding juga sama-sama mendapatkan asupan energi yang sama. Yang berbeda hanya dari sisi kualitas makanannya.

Tambahan energi lebih banyak pada makan sore di rumah. Pada anak yang sekolah dengan model school feeding asupan energi sore hari setelah pulang sekolah lebih banyak dibandingkan dengan anak yang sekolah dengan model non school feeding. Jika ditinjau dari tingkat penghasilan orang tua, anak yang sekolah di sekolah dengan model school feeding rata-rata dari kalangan ekonomi menengah ke atas, sehingga kemampuan membeli bahan makan bernilai gizi tinggi lebih baik dibandingkan orang tua anak pada model non school feeding.

\section{b. Perbedaan asupan Protein pada anak dengan model school feeding dan non school feeding}

Protein merupakan makronutien yang penting untuk semua kelompok umur. Sumbangan kalori protein $10-15 \%$ dari total kalori dalam 
diet seseorang, tetapi protein merupakan komponen struktural dan fungsional dalam semua sel di tubuh kita. ${ }^{14}$

Hasil penelitian ini menunjukkan ada perbedaan yang signifikan asupan protein sehari pada anak dengan model school feeding dan non school feeding dengan nilai $p$ value 0,000 . Asupan protein sehari pada anak dengan model school feeding lebih tinggi yaitu 146.74 persen AKG, jika dibanding dengan asupan protein pada anak dengan model non school feeding yaitu 103,24 persen AKG. Walaupun ada perbedaan rerata yang signifikan namun jika dilihat berdasarkan persen AKG pada kedua kelompok tersebut mempunyai asupan protein yang cukup. ${ }^{14}$

Akan tetapi asupan protein pada siang hari tidak menunjukkan perbedaan yang signifikan. Hasil penelitian Sukendro (2012) pada lokasi yang sama menemukan bahwa tidak ada perbedaan yang signifikan asupan protein siang hari pada anak yang sekolah dengan model school feeding dan non school feeding dengan nilai $p$ value $0,384 .{ }^{13}$ Hal ini terjadi karena pada anak dengan model school feeding asupan protein sore dan malam hari setelah pulang sekolah lebih tinggi jika dibandingkan dengan anak dengan model non school feeding. Faktor penyediaan makanan keluarga yang cukup pada anak dengan model school feeding mempengaruhi jumlah asupan protein pada anak dengan model school feeding. Selain itu pada anak dengan dengan model school feeding, model pembelajaran sehari memungkinkan pengeluaran energi dan tingkat kecapaian lebih tinggi dibandingkan dengan anak dengan model non school feeding, sehingga nafsu makan sore hari lebih tinggi.

Hasil penelitian ini sejalan dengan penelitian Wati (2006) yang mengatakan bahwa ada perbedaan yang signifikan konsumsi protein sehari pada kelompok anak dengan model katering dan non katering. Pada penelitian peneliti memfokuskan pada perbedaan asupan zat gizi, status gizi dan prestasi belajar berdasarkan penyelenggaraan makanan di sekolah yaitu model katering dan non katering. Perbedaan penelitian Wati dengan peneliti yaitu pada subjek penelitian, lokasi dan variabel lain yang diteliti. ${ }^{15}$

\section{c. Perbedaan Status Gizi (Z score) pada anak dengan model school feeding dan non school feeding}

Hasil penelitian ini menunjukkan ada perbedaan rata-rata nilai $\mathrm{z}$ score antara anak yang sekolah di model school feeding dan non school feeding. Pada anak yang sekolah di sekolah dengan model school feeding rata-rata nilai $z$ scorenya lebih tinggi yaitu $-0,1397$ dibandingkan dengan anak yang sekolah di sekolah dengan model non school feeding yaitu 0,9749 . Tingginya rata-rata $z$ score anak yang sekolah di sekolah dengan model school feeding disebabkan karena asupan energi dan protein pada anak yang sekolah dengan model school feeding juga lebih tinggi. Ratarata asupan energi anak yang sekolah dengan model school feeding 103,06 persen akg sedang rata-rata asupan energi anak yang sekolah di sekolah dengan model non school feeding hanya mencapai 80,82 persen AKG.

Kecukupan energi berhubungan dengan status gizi. Energi yang cukup memungkinkan anak untuk bisa melaksanakan kegiatannya seharihari seperti bermain, belajar, berekreasi dan untuk tumbuh. Tanda seseorang memenuhi kecukupan energi dapat dilihat dari kenaikan berat badannya. $^{16}$

Hasil uji korelasi menggunakan person korelasi menunjukkan ada hubungan yang signifikan antara asupan energi dengan rata-rata nilai $z$ score. Asupan energi dan protein berhubungan dengan status gizi. Menurut 
Supariasa (2002) status gizi merupakan manifestasi dari asupan dan pengeluaran energi. ${ }^{10}$ Jika masukan lebih sedikit dari pengeluaran maka akan berakibat menurunnya status gizi, sebaliknya jika asupan lebih tinggi dari pengeluaran energi maka dalam jangka waktu tertentu akan menyebabkan obesitas. Hasil penelitian ini sejalan dengan penelitian Sulistyowati (2010) yang mengatakan bahwa status gizi anak sekolah dasar yang sekolah dengan model school feeding lebih baik jika dibandingkan dengan status gizi anak yang sekolah dengan model non school feeding. ${ }^{4}$

Perbedaan penelitian ini dengan penelitian Sulistyowati yaitu pada subjek penelitian dan lokasi penelitian. Pada penelitian Sulistyawati subjek penelitian yaitu anak sekolah dasar sedangkan pada penelitian ini subjek penelitian adalah anak usia pra sekolah. ${ }^{4}$ Hasil penelitian ini juga sejalan dengan penelitian Ikeu, dkk (2013) yang mengatakan bahwa ada perbedaan status gizi pada anak sekolah dasar sebelum dan sesudah diberi kudapan di sekolah. Pada penelitian Ikeu design yang dipakai yaitu eksperimental pre post design. ${ }^{17}$

Hasil penelitian ini berbeda dengan hasil penelitian Mayasari. Pada penelitian Mayasari (2011) ditemukan tidak ada perbedaan yang signifikan status gizi anak sekolah dasar yang mendapat pemberian makanan tambahan anak sekolah (PMT AS) dan tidak mendapatkan pemberian makanan tambahan anak sekolah tetapi ada perbedaan frekuensi jajan antara anak sekolah dasar yang mendapat pemberian makanan tambahan anak sekolah dan yang tidak mendapat pemberian makanan tambahan anak sekolah. ${ }^{18}$

Perbedaan hasil penelitian ini dengan penelitian Mayasari dapat disebabkan karena subjek dan jenis perlakuan yang berbeda. Pada penelitian mayasari yang diteliti yaitu sekolah dasar penerima PMT AS dan bukan penerima PMT AS, sedangkan pada penelitian ini yang diteliti ada sekolah yang menyelenggarakan makan disekolah baik makan besar (siang hari) dan kudapan. ${ }^{18}$

\section{SIMPULAN DAN SARAN}

\section{A. Simpulan}

Ada perbedaan asupan energi, asupan protein dan status gizi anak yang sekolah dengan model school feeding dan non school feeding.

\section{B. Saran}

1. Untuk pengelola TK model school feeding diharapkan lebih meningkatkan mutu pelayanan menu makanan di sekolah, agar asupan gizi anak di sekolah tetap terjaga.

2. Untuk pengelola TK model non school feeding diharapkan lebih aktif memberikan penyuluhan kepada orang tua wali berkaitan dengan gizi anak usia pra sekolah agar status gizi anak dapat lebih ditingkatkan.

\section{DAFTAR PUSTAKA}

1. Atmarita, Nutrition problem in Indonesia, Artikel disampaikan pada seminar dan workshop Gaya Hidup Hubungannya dengan Penyakit, Universitas Gadjah Mada, Yogyakarta. 2005.

2. Atmarita, F., Tatang S., Analisis Situasi Gizi dan Kesehatan Masyarakat, Artikel disajikan pada Widyakarya Nasional Pangan dan Gizi VII, Jakarta. 2004. 
3. Hadi, H., Beban Ganda Masalah Gizi dan Implikasinya terhadap Kebijakan Pembangunan Nasional, Pidato Pengukuhan Guru Besar Universitas Gadjah Mada, Yogyakarta. 2005.

4. Sulistyowati, T.F., Perbedaan Asupan Makan, Status Gizi dan Tingkat Konsentrasi belajar siswa disekolah dengan school feeding dan non school feeding, Skripsi, Prodi Ilmu Gizi Fakultas Kedokteran, UGM, Yogyakarta. 2010.

5. Simeon, D.T., School Feeding in Jamaican ; a review of its evaluation, Am J Clin Nutr, 67, 790 S - 4 S. 1998.

6. Murti, B., Prinsip dan Metode Riset Epidemiologi, UGM Press, Yogyakarta. 2001.

7. Sabri, L., Hastono, S.P., Statistik Kesehatan, Rajagrafindo Persada, Jakarta. 2006.

8. Beck, M. E., IImu Gizi dan Diet, Penerbit Andi, Yogyakarta. 2011.

9. Almatsier, S, Prinsip Dasar IImu Gizi, PT Gramedia Pustaka Utama, Jakarta. 2003.

10. Supariasa, I.D.N., Penilaian Status Gizi, Penerbit Buku Kedokteran EGC, Jakarta. 2002.

11. Rumah Sakit Cipto Mangunkusumo dan Persagi, Penuntun Diit Anak, Jakarta. 2003.

12. Adriani, M., Wirjatmadi, B., Pengantar Gizi Kesehatan Masyarakat, Kencana Prenada Media Group, Jakarta. 2012.

13. Sukendro, N., Sunarti, Perbedaan Asupan Energi dan Protein pada Siang Hari antara Anak Taman Kanak-Kanak di Sekolah dengan Model School Feeding dan Non School Feeding, Jurnal Kesehatan Masyarakat Universitas Ahmad Dahlan, Yogyakarta. 2012.

14. Garrow, JS. Games, WTP. Ralph, A., Human Nutrition and Dietetics, Churchill Livingstone, Edinburgh London New York. 2000.

15. Wati, Y.R., Perbedaan Tingkat Konsumsi Zat Gizi, Status Gizi dan Prestasi Belajar berdasarkan Penyelenggaraan Makanan, Skripsi, Prodi IImu Gizi Fakultas Kedokteran, UNDIP, Semarang. 2006.

16. Adriani, M., Wirjatmadi, B., Peranan Gizi Dalam Sikles Kehidupan, Kencana Prenada Media Group, Jakarta. 2012.

17. Ikeu, T., Prasojo, G., Rahmawati, Irawati, M., Rusmawati, D., Pengaruh Pemberian Kudapan terhadap Status Gizi dan Status Anemia Siswa SDN Pasanggrahan 2 Purwakarta, Respiratory IPB, Bogor. 2013.

18. Mayasari, D., Perbedaan Asupan Energi Protein, Frekuensi Jajan di Sekolah dan Status Gizi antara Anak Sekolah Dasar Penerima dan bukan Penerima Program Pemberian Makanan Tambahan anak Sekolah, Skripsi, Prodi ilmu Gizi Fakultas Kedokteran, UNDIP, Semarang. 2011. 